\title{
THE EFFECT OF PRODUCT QUALITY AND PROMOTION ON CONSUMER PURCHASING DECISIONS
}

\author{
Kiki Dwi Wijayanti \\ Universitas Pamulang, Indonesia \\ dosen02247@unpam.ac.id
}

\begin{abstract}
This study aims to determine the effect of product quality and promotion on consumer purchasing decisions at Floris Florists in Jakarta. The method used is explanatory research with analytical techniques using statistical analysis with regression testing, correlation, determination, and hypothesis testing. The results of this study product quality significantly influence consumer purchasing decisions by $40.9 \%$, the hypothesis test obtained $t$ count $>t$ table or (8.069>1.986). The promotion has a significant effect on consumer purchasing decisions by $39.3 \%$, the hypothesis test is obtained t count $>t$ table or $(7.796>1.986)$. Product quality and promotion simultaneously have a significant effect on consumer purchasing decisions with a regression equation $\mathrm{Y}=10.681+0.382 \mathrm{X} 1+0.361 \mathrm{X} 2$ and an influential contribution of $50.2 \%$, the hypothesis test is obtained $F$ count $>F$ table or $(46.890>2.700)$.
\end{abstract}

Keywords: Product Quality, Promotion, Consumer purchasing decisions

\section{INTRODUCTION}

Creating a strong and close relationship with customers is the goal of all marketers, this is a successful success in forming customer ties and customer satisfaction is closely related to the benefits it receives, can provide several benefits including relationships between companies and customers in harmony and provide strong references and word of mouth that benefits the company. "Satisfied customers will have implications on the minds of consumers and make customers more trustworthy.

Marketing is an activity and process of creating, communicating, giving, and offering an exchange of values to customers, clients, partners, and the wider community. Sudaryono (2017) Marketing is a management process that identifies, anticipates, and provides what customers want efficiently and profitably (Sule \& Saefullah, 2010). To conduct business, it is necessary to have a business entity both a legal entity and a non-legal entity. In individual businesses, both UD and PD, it can be assumed that these businesses are micro-scale businesses. This is following the definition of a micro business in Law No. 20 of 2008 concerning Micro, Small, and Medium
Enterprises (UU-UMKM), namely Micro Business is productive businesses owned by individuals and/or individual business entities that meet the criteria of Micro Business.

Related to the form of business, then the implementing regulations of the MSME Law are through PP No. 17 of 2013, the definition concerning the form of a micro business is mentioned, namely: Business License is written evidence given by the authorized official based on the provisions of the legislation as proof of legality that states that the legal business Micro, Small Business, and Medium Business has fulfilled the requirements and allowed to run a certain business activity. The statement about the proof of legality, in this case, must be related to the legality of the establishment of the business. The aforementioned permit procedure is stated that it is a permit procedure regulated in the provisions of the legislation. This means returning to the rules governing the legality of the establishment that micro-scale businesses or individual businesses.

In the Law on Compulsory Company Registration distinguishes between companies and entrepreneurs. Company is any form of business that runs every type of business that is 
permanent and continuous and which is established, working and domiciled within the territory of the Republic of Indonesia, to obtain profits and / or profits. While the entrepreneur is every individual or association or legal entity that runs a type of company.

Article 6 paragraph (1) b states that: Every Individual Small Company is run by a private entrepreneur or employs only the nearest family member and does not require a business license and does not constitute a legal entity or a partnership. This means that compulsory company registration does not require individual small companies in this sense.

Marketing activities implemented by the company are said to be successful if it is proven by increasing sales volume decreases when marketing activities are applied inappropriately. This makes the important role of promotion for the company.

In Floris Florist business in marketing their product types, they carry out marketing activities by word of mouth, online offline. Lack of variation in production, such as from year to year the production model is always the same, raw materials change, in terms of material thickness, perishability, lack of color combinations, and lack of popularity of ornamental flower products are obstacles Floris Florists in marketing their products. Since 1978, Florist has been known as a florist that provides a variety of quality fresh flower arrangements for bouquets, flower boards, table flowers, and various other flower arrangements for special moments.

For the design and decoration of these flowers, the company always provides high-quality fresh flowers, innovative ideas, and of course, the best service. Orchid Florist \& Decoration also provides a touch of elegance and contemporary that is right for the needs of consumers. Every story is a special story. Therefore, the company offers unique and different designs to celebrate every wedding and another special event. The company even works with the best designers and designers to bring your story to life through beautiful flower arrangements and decorations. Not only that, but the company also offers all-in-one florist services such as working on floral arrangement decorations for offices, hotels, retail stores, restaurants, bars, and other businesses. In every company job, the company also always takes into account the freshness, durability, and overall appearance of the series.

As a florist specialist, the company's flower shop serves from care, decoration, to flower delivery in Jakarta, Surabaya, and various regions in Indonesia. In marketing, Floris utilizes technology that develops with the internet, social media, banner, poster, and brochure making. Now, ordering flowers is made easier with Florist flower delivery services, which can be done by ordering flowers online.

Based on the thoughts that have been described, the writer is interested to do with the title: "The Effect of Product Quality and Promotion on Consumer Purchasing Decisions in Florist Florists in Jakarta".

Formulation of the problem: (1) Is there a partial effect between product quality on consumer purchasing decisions at Floris Florists in Jakarta; (2) Is there a partial influence between promotions on consumer purchasing decisions at Floris Florists in Jakarta; (3) Is there a simultaneous influence between product quality and promotion on consumer purchasing decisions at Floris Florists in Jakarta.

Research purposes: (1) To determine the partial effect between product quality on consumer purchasing decisions at Floris Florists in Jakarta; (2) To find out partial influence between promotions on consumer purchasing decisions at Floris Florists in Jakarta; (3) To find out the simultaneous influence between product quality and promotion on consumer purchasing decisions at Floris Florists in Jakarta. 
According to Zimmerer and Scarborough (2011) that products are goods or services that are used to satisfy consumer needs. According to Simamora (2012) the product is an offer from a company that satisfies or meets customer needs. Another case with the opinion of Kotler and Armstrong (2012) which defines that the product is something that can be offered to the market to be considered, owned, used, or consumed that can satisfy desires and needs.

It can be concluded that the product is not only in the form of real goods but can be in the form of services, then the product can provide different satisfaction so that companies are demanded to be more creative and have a wide view of the products produced

The efforts made by the company in introducing or providing information to the public and customers. Promotion is seen as a one-way flow of information or activities in persuading customers so that customers want to make purchases and process transactions. This process is very important because promotion can provide information that can be directly understood by the buyer and ultimately the buying process.

According to Stanton (2011) Marketing as a whole internal related to activities and businesses that have the aim to plan to price, promote and distribute goods and services that will satisfy the needs of both existing buyers and potential buyers. Meanwhile, according to Suryadi (2011) defines promotion is a series of activities to communicate and convince people about these products and bind their minds and markets in a form of loyalty to the product.

Talking about behavior with customers, a marketer must take into account the effectiveness of the steps in determining the marketing strategy that must be carried out. Knowing, understanding the characteristics and aspects of marketing is important to influence and ensure the customer will buy or not. According to Splomon, quoted by Jasmani (2018) said that the study of consumer behavior is a process, when individuals or groups select, buy, use or dispose of products, services, ideas, and experiences to satisfy their needs. Meanwhile according to Kotler \& Keller (2012) defines that the customer decision process consists of several stages that must be carried out by the customer before the purchase decision and then post-purchase. Furthermore, Kotler \& Keller (2012) expressed the purchase decision as to the decision stage where the consumer purchases a product.

\section{METHODS}

The population in this study amounted to 96 respondents Floris Florist in Jakarta. The sampling technique in this study is saturated sampling, where all members of the population are sampled. Thus the sample in this study amounted to 96 respondents. The type of research used is associative, where the aim is to determine the effect of independent variables on both partial and simultaneous dependent variables. In analyzing the data used the instrument test, classical assumption test, regression, coefficient of determination, and hypothesis testing.

\section{RESULTS AND DISCUSSION Descriptive Analysis}

This test used to determine the minimum and maximum scores, mean scores, and standard deviations of each variable. The results are as follows: 
Table 1. Results of Descriptive Statistics Analysis

\begin{tabular}{cccccc}
\hline & \multicolumn{3}{c}{ Descriptive Statistics } & & \\
& $\mathrm{N}$ & Minimum & Maximum & Mean & Std. Deviation \\
\hline Product quality (X1) & 96 & 32 & 48 & 38.30 & 3.825 \\
Promotion (X2) & 96 & 30 & 45 & 38.32 & 3.723 \\
Consumer purchasing & 96 & 32 & 46 & 39.15 & 3.539 \\
$\quad$ decisions (Y) & & & & & \\
Valid N (listwise) & 96 & & & & \\
\hline
\end{tabular}

Source: processed data (2020)

Product quality obtained a minimum variance of 32 and a maximum variance of 48 with a mean score of 3.83 with a standard deviation of 3.825 . Promotion obtained a minimum variance of 30 and a maximum variance of 45 with a mean score of 3.83 with a standard deviation of 3.723. Consumer purchasing decisions obtained a minimum variance of 32 and a maximum variance of 46 with a mean score of 3.91 with a standard deviation of 3.539 .

\section{Verification Analysis}

This analysis is intended to determine the effect of independent variables on the dependent variable. The test results are as follows:

\section{Multiple Linear Regression Analysis}

This regression test is intended to determine changes in the dependent variable if the independent variable changes. The test results are as follows:

Table 2. Results of Multiple Linear Regression Testing

\begin{tabular}{|c|c|c|c|c|c|c|}
\hline \multicolumn{6}{|c|}{ Coefficients $^{a}$} & \\
\hline & \multirow[t]{2}{*}{ Model } & \multicolumn{2}{|c|}{$\begin{array}{l}\text { Unstandardized } \\
\text { Coefficients }\end{array}$} & \multirow{2}{*}{$\begin{array}{c}\text { Standardized } \\
\text { Coefficients } \\
\text { Beta }\end{array}$} & \multirow[t]{2}{*}{$\mathrm{t}$} & \multirow[t]{2}{*}{ Sig. } \\
\hline & & B & Std. Error & & & \\
\hline 1 & (Constant) & $\begin{array}{c}10.68 \\
1\end{array}$ & 2.954 & & 3.616 & .000 \\
\hline & roduct quality $(\mathrm{X} 1)$ & .382 & .084 & .413 & 4.520 & .000 \\
\hline & Promotion (X2) & .361 & .087 & .380 & 4.165 & .000 \\
\hline & a. Depend & Variable & Jonsumer & asing deci & & \\
\hline
\end{tabular}

Based on the test results in the above table, the regression equation $Y=$ $10.681+0.382 \mathrm{X} 1+0.361 \times 2$ is obtained. From the equation explained as follows: A constant of 10,681 is interpreted if the quality of the product and promotion does not exist, then there has been a value of consumer purchasing decisions of 10.681 points. Product quality regression coefficient of 0.382 , this number is positive, meaning that every time there is an increase in product quality by 0.382 , consumer purchasing decisions will also increase by 0.382 points. The promotional regression coefficient of 0.361 , this number is positive, meaning that every time there is an increase in promotion of 0.361 , consumer purchasing decisions will also increase by 0.361 points.

\section{Correlation Coefficient Analysis}

Correlation coefficient analysis is intended to determine the degree of relationship strength of the independent variables on the dependent variable either partially or simultaneously. The test results are as follows: 
Table 3. Correlation Coefficient Testing Results Product Quality Against Consumer Purchasing Decisions

\begin{tabular}{|c|c|c|c|}
\hline \multicolumn{4}{|c|}{ Correlations $^{b}$} \\
\hline & & $\begin{array}{c}\text { Product } \\
\text { quality }(\mathrm{X} 1)\end{array}$ & $\begin{array}{c}\text { Consumer } \\
\text { purchasing } \\
\text { decisions }(Y)\end{array}$ \\
\hline \multirow[t]{2}{*}{ Product quality (X1) } & $\begin{array}{l}\text { Pearson } \\
\text { Correlation }\end{array}$ & 1 & $.640^{* *}$ \\
\hline & Sig. (2-tailed) & & .000 \\
\hline $\begin{array}{l}\text { Consumer purchasing } \\
\text { decisions }(\mathrm{Y})\end{array}$ & Pearson & $.640^{* *}$ & 1 \\
\hline${ }^{* \star}$. Correl & $\begin{array}{l}\text { Sig. (2-tailed) } \\
\text { is significant at } \\
\text { b. Listwise }\end{array}$ & $\begin{array}{l}.000 \\
0.01 \text { level }(2-\mathrm{t} \\
6\end{array}$ & \\
\hline
\end{tabular}

Based on the test results obtained a correlation value of 0.640 means that product quality has a strong relationship with consumer purchasing decisions.

Table 4. Test Results for Promotion Correlation Coefficients Against Consumer Purchasing Decisions

\begin{tabular}{|c|c|c|c|}
\hline \multicolumn{4}{|c|}{ Correlations $^{b}$} \\
\hline & & $\begin{array}{l}\text { Promotion } \\
\text { (X2)) }\end{array}$ & $\begin{array}{c}\text { Consumer } \\
\text { purchasing } \\
\text { decisions }(\mathrm{Y})\end{array}$ \\
\hline \multirow[t]{2}{*}{ Promotion (X2) } & $\begin{array}{l}\text { Pearson } \\
\text { Correlation }\end{array}$ & 1 & $.627^{* *}$ \\
\hline & Sig. (2-tailed) & & .000 \\
\hline \multirow{2}{*}{$\begin{array}{c}\text { Consumer } \\
\text { purchasing } \\
\text { decisions }(\mathrm{Y})\end{array}$} & $\begin{array}{l}\text { Pearson } \\
\text { Correlation }\end{array}$ & $.627^{* *}$ & 1 \\
\hline & Sig. (2-tailed) & .000 & \\
\hline **. Cor & $\begin{array}{r}\text { is significant a } \\
\mathrm{b} \text {. Listwise }\end{array}$ & $\begin{array}{l}0.01 \text { level }(2- \\
6\end{array}$ & \\
\hline
\end{tabular}

Based on the test results obtained a correlation value of 0.627 means that promotion has a strong relationship with consumer purchasing decisions.

Table 5. Test Results Correlation Coefficients Product quality and Promotion simultaneously on consumer purchasing decisions

\begin{tabular}{|c|c|c|c|c|}
\hline Model Summary & & & & \\
\hline Model $\quad R$ & R Square & $\begin{array}{l}\text { Adjusted } \\
\text { Square }\end{array}$ & $\mathrm{R}$ & $\begin{array}{l}\text { Std. Error of the } \\
\text { Estimate }\end{array}$ \\
\hline $.709^{a}$ & .502 & .491 & & 2.524 \\
\hline
\end{tabular}

Source: processed data (2020)

Based on the test results obtained by the correlation value of 0.709 means that product quality and promotion simultaneously have a strong relationship to consumer purchasing decisions. 
Analysis of the Coefficient of Determination

Analysis of the coefficient of determination is intended to determine the percentage of influence of the independent variable on the dependent variable either partially or simultaneously. The test results are as follows:

Table 6. Testing Results Determination Coefficient Product quality on consumer purchasing decisions

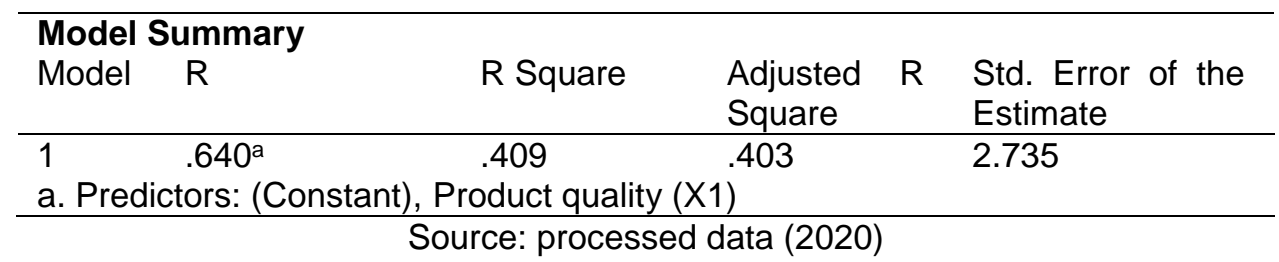

Based on the test results obtained a determination value of 0.409 means that product quality has an influence contribution of $40.9 \%$ on consumer purchasing decisions.

Table 7. Test Results for Promotion Determination Coefficient on Consumer purchasing decisions

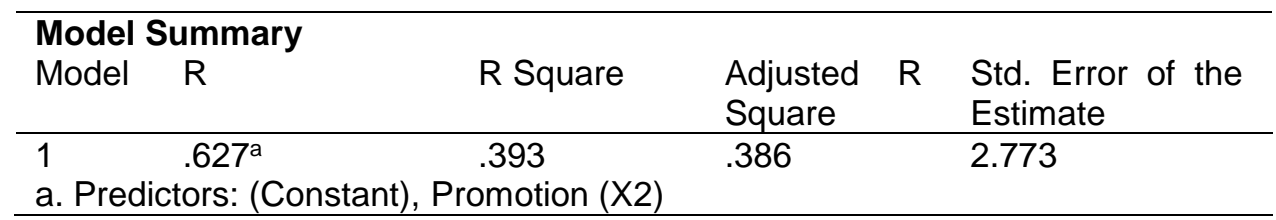

Source: processed data (2020)

Based on the test results obtained a determination value of 0.393 means that promotion has an influence contribution of $39.3 \%$ on consumer purchasing decisions.

Table 8. Testing Results Determination Coefficient Product quality and Promotion of consumer purchasing decisions

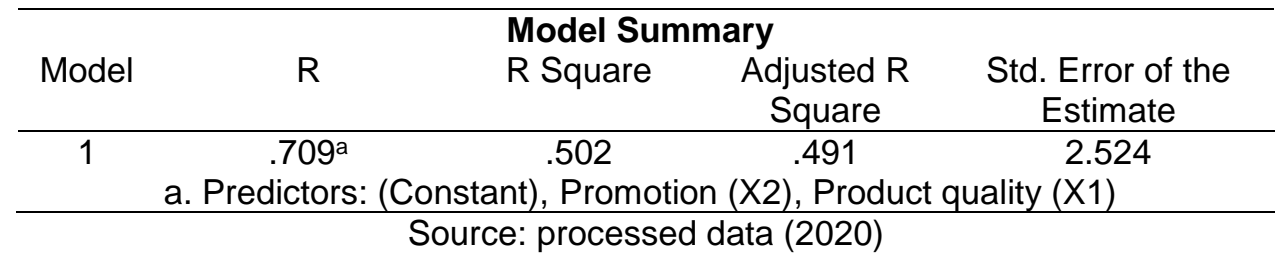

Based on the test results obtained a determination value of 0.502 means that product quality and promotion simultaneously have an influence contribution of $50.2 \%$ on consumer purchasing decisions, while the remaining $49.8 \%$ is influenced by other factors.

\section{Hypothesis testing}

Hypothesis testing with a t-test is used to find out which partial hypotheses are accepted.

First Hypothesis: There is a significant influence between product quality on consumer purchasing decisions. 
Table 9. Hypothesis Test Results Product quality Against consumer purchasing decisions

\begin{tabular}{|c|c|c|c|c|c|c|}
\hline \multicolumn{7}{|c|}{ Coefficients $^{a}$} \\
\hline & \multirow[t]{2}{*}{ Model } & \multicolumn{2}{|c|}{$\begin{array}{l}\text { Unstandardized } \\
\text { Coefficients }\end{array}$} & \multirow{2}{*}{$\begin{array}{c}\text { Standardiz } \\
\text { ed } \\
\text { Coefficient } \\
\text { s } \\
\text { Beta }\end{array}$} & \multirow[t]{2}{*}{$\mathrm{t}$} & \multirow[t]{2}{*}{ Sig. } \\
\hline & & B & Std. Error & & & \\
\hline 1 & (Constant) & $\begin{array}{c}16.47 \\
8\end{array}$ & 2.823 & & 5.837 & .000 \\
\hline & $\begin{array}{l}\text { Product quality } \\
\text { (X1) } \\
\text { a. Dependen }\end{array}$ & .592 & onsumer $\mathrm{p}$ & lasing dec & 8.069 & .000 \\
\hline
\end{tabular}

Source: processed data (2020)

Based on the test results in the above table, the value of $t$ count $>t$ table or $(8.069>1.986)$ is obtained, thus the first hypothesis proposed that there is a significant influence on the quality of the product on consumer purchasing decisions is accepted.

Table 10. Results of the Promotional Hypothesis Test Against Consumer purchasing decisions

\begin{tabular}{|c|c|c|c|c|c|c|}
\hline \multicolumn{7}{|c|}{ Coefficients $^{a}$} \\
\hline & \multirow[t]{2}{*}{ Model } & \multicolumn{2}{|c|}{$\begin{array}{l}\text { Unstandardized } \\
\text { Coefficients }\end{array}$} & $\begin{array}{l}\text { Standardized } \\
\text { Coefficients }\end{array}$ & $\mathrm{t}$ & Sig. \\
\hline & & $\mathrm{B}$ & Std. Error & Beta & & \\
\hline \multirow[t]{2}{*}{1} & (Constant) & $\begin{array}{c}16.31 \\
8\end{array}$ & 2.942 & & $\begin{array}{l}5.54 \\
7\end{array}$ & .000 \\
\hline & Promotion (X2) & .596 & .076 & 627 & $\begin{array}{c}7.79 \\
6\end{array}$ & .000 \\
\hline
\end{tabular}

a. Dependent Variable: Consumer purchasing decisions $(\mathrm{Y})$ Source: processed data (2020)

Based on the test results in the table above, the value of $t$ count $>t$ table or $(7.796>1.986)$ is obtained, thus the second hypothesis proposed that there is a significant influence between promotion on consumer purchasing decisions is accepted.
Hypothesis testing with the F test is used to find out which simultaneous hypotheses are accepted.

The third hypothesis There is a significant influence between product quality and promotion on consumer purchasing decisions.

Table 11. Hypothesis Test Results for Product Quality and Promotion of Consumer purchasing decisions

\begin{tabular}{|c|c|c|c|c|c|c|}
\hline \multirow[b]{2}{*}{ Model } & & \multicolumn{3}{|c|}{ ANOVA $^{a}$} & \multirow[b]{2}{*}{$\mathrm{F}$} & \multirow[b]{2}{*}{ Sig. } \\
\hline & & $\begin{array}{l}\text { Sum } \\
\text { Squares }\end{array}$ & of $\quad d f$ & $\begin{array}{l}\text { Mean } \\
\text { Square }\end{array}$ & & \\
\hline 1 & $\begin{array}{l}\text { Regression } \\
\text { Residual } \\
\text { Total }\end{array}$ & $\begin{array}{l}597.465 \\
592.493 \\
1189.958\end{array}$ & $\begin{array}{l}2 \\
93 \\
95\end{array}$ & $\begin{array}{l}298.733 \\
6.371\end{array}$ & 46.890 & $.000^{\mathrm{b}}$ \\
\hline
\end{tabular}


Based on the test results in the table above, the calculated $\mathrm{F}$ value $>\mathrm{F}$ table or $(46.890>2,700)$, thus the third hypothesis proposed that there is a significant influence between product quality and promotion on consumer purchasing decisions is accepted.

\section{Effect of product quality on consumer purchasing decisions \\ Product quality has a significant} effect on consumer purchasing decisions with a correlation of 0.640 or has a strong relationship with a contribution of $40.9 \%$. Hypothesis testing obtained $\mathrm{t}$ value $>\mathrm{t}$ table or (8.069>1.986). Thus the first hypothesis proposed that there is a significant effect between product quality on consumer purchasing decisions is accepted.

\section{Effect of Promotion on Consumer purchasing decisions}

The promotion has a significant effect on consumer purchasing decisions with a correlation of 0.627 or has a strong relationship with a contribution of $39.3 \%$. Hypothesis testing obtained $\mathrm{t}$ value $>\mathrm{t}$ table or (7.796> 1.986). Thus the second hypothesis is proposed that there is a significant influence between promotions on consumer purchasing decisions accepted.

\section{Effect of product quality and promotion on consumer purchasing decisions}

Product quality and promotion have a significant effect on consumer purchasing decisions by obtaining a regression equation $\mathrm{Y}=10.681+$ $0.382 X 1+0.361 X 2$, a correlation value of 0.709 or have a strong relationship with a contribution of $50.2 \%$ while the remaining $49.8 \%$ is influenced by factors other. Hypothesis testing obtained $\mathrm{F}$ value $>\mathrm{F}$ table or $(46.890>2,700)$. Thus the third hypothesis proposed that there is a significant effect between product quality and promotion of consumer purchasing decisions is accepted.

\section{CONCLUSION}

Product quality has a significant influence on consumer purchasing decisions. Hypothesis testing obtained value $t>t_{\text {table. }}$. The promotion has a significant influence on consumer purchasing decisions. Hypothesis testing obtained $t_{\text {count }}>t_{\text {table. }}$. Product quality and promotion have a significant effect on consumer purchasing decisions Hypothesis testing is obtained with a calculated $F$ value $>F$ table

\section{REFERENCES}

Jasmani, J. (2018). Pengaruh Kualitas Produk Dan Harga Terhadap Keputusan Pembelian Pada PT. Baja Mandiri Di Jakarta. Disrupsi Binis, 1(1).

Kotler, Philip \& Amstrong, Gary. (2012) Dasar-Dasar Pemasaran.Jilid I, Alih Bahasa Alexander Sindoro dan Benyamin Molan. Jakarta: Penerbit Prenhalindo

Kotler, Philip, and Keller, Kevin Lane. (2012). Marketing Management, Edisi 14. New Jersey: PrenticeHall Published.

Simamora, Bilson. (2012). Panduan Riset Dan Perilaku Konsumen. Jakarta: PT Gramedia Pustaka Utama.

Stanton, William J. (2011). Prinsip pemasaran, alih bahasa: Yohanes Lamarto. Jakarta: Erlangga.

Sudaryono. (2017). Metodologi Penelitian. Jakarta: PT Raja Grafindo Persada

Sule, E. T., \& Saefullah, K. (2010). Pengantar Manajemen. Edisi 1. Jakarta: Kencana Predana Media Group. ISBN: 979-3456-75-1

Suryadi, Didih. (2011). Promosi Efektif Menggugah Minat \& Loyalitas Pelanggan. Jakarta : PT. Suka Buku.

Zimmerer, Thomas $\mathrm{W} \&$ \& Scarborough, Norman M. (2011). Kewirausahaan dan Manajemen. Usaha Kecil. Jakarta: Salemba empat. 